\title{
Antystatyzacja tworzyw sztucznych w celu uniknięcia zagrożenia wybuchem
}

\author{
Production of Anti-static Plastics to Avoid the Threat of Explosion
}

\section{Антистатизация пластмассы с целью избежания угрозы взрыва}

\begin{abstract}
ABSTRAKT
Cel: Tworzywa sztuczne zakwalifikowane do izolatorów elektrycznych nie spełniają kryteriów polskich i międzynarodowych norm [1], [2], [3], [4] oraz polskiej legislacji [5] odnośnie właściwości antyelektrostatycznych, wobec czego nie mogą być dopuszczone do użytkowania w strefach zagrożonych wybuchem. W celu spełnienia wymagań wyżej wymienionych norm i przepisów, uzyskania wyrobu antystatycznego oraz obniżenia ryzyka wyładowania elektrostatycznego mogącego być inicjatorem wybuchu tworzywa sztuczne poddaje się antystatyzacji, czyli poprawianiu właściwości antyelektrostatycznych (głównie zmniejszeniu rezystancji i rezystywności). Projekt i metoda: Przedstawiono wyniki prowadzonych badań właściwości elektrostatycznych wyrobów. Z analizy parametrów elektrycznych, statycznych (rezystancja powierzchniowa, skrośna oraz między punktami) i dynamicznych (czas zaniku ładunku, zdolność do elektryzacji, natężenie pola elektrycznego), analizy stabilności w czasie parametrów elektrycznych, wpływu na środowisko wyrobów antystatyzowanych uzyskano autorską charakterystykę procesu antystatyzacji, którą przedstawiono w publikacji. Wybrano wyroby reprezentujące różne metody i sposoby realizacji tego procesu. Pomimo że technologia antystatyzacji jest znana, to nie jest ona gruntownie rozpoznana i opisana między innymi w zakresie trwałości w czasie.

Antystatyzacja jest procesem polegającym na zwiększeniu szybkości rozpraszania (odprowadzania) ładunków. Na szybkość rozładowania decydujący wpływ ma pojemność elektryczna wyrobu i jego rezystancja. Antystatyzacja polega na modyfikacji dwóch parametrów wyrobów: zmianie pojemności elektrycznej oraz zmianie rezystancji elektrycznej wyrobów.

Wyniki: W ramach pracy badawczej, realizowanej w Głównym Instytucie Górnictwa od 2012 roku, przeprowadzono szereg kompleksowych badań, które zaowocowały zaproponowaniem podziału technik antystatyzacji z uwagi na jej różnorodny charakter i typy. Na podstawie szeregu badań dużej liczby różnorodnych wyrobów i materiałów zaproponowano podział technik antystatyzacji, który jest rozszerzeniem i uzupełnieniem dotychczas istniejących w specjalistycznej literaturze klasyfikacji.

Wnioski: Wyniki pracy mogą być wykorzystane przy projektowaniu procesów przetwórstwa tworzyw sztucznych celem opracowania technologii produkcji wyrobów antystatycznych, których właściwości antystatyczne są trwałe w czasie oraz celem analizy ryzyka związanego z elektryzacją wyrobu.
\end{abstract}

Słowa kluczowe: elektryczność statyczna, elektrostatyka, antystatyzacja, elektryzacja, rezystancja Typ artykułu: oryginalny artykuł naukowy

\section{A BSTRACT}

Aim: Plastics used as electrical insulators do not fulfil the criteria for Polish and international standards [1], [2], [3], [4] and Polish legislation [5], with regard to anti-static properties. Therefore, such materials cannot be approved for use in potentially explosive environments. In order to satisfy the requirements of the aforementioned standards and regulations, and produce a product with anti-static properties, thus reducing the risk of an electrostatic discharge, which could initiate the explosive fragmentation of plastic materials, there is a need to improve anti-static properties of plastics mainly by reducing their level of resistance and resistivity.

\footnotetext{
Wyższa Szkoła Zarządzania Ochroną Pracy, Katowice / University of Labour Safety Management in Katowice, Poland; wkład merytoryczny w powstanie artykułu / percentage contribution - 30\%;

2 Główny Instytut Górnictwa, Katowice / Central Mining Institute in Katowice, Poland; pkedzierski@gig.eu; wkład merytoryczny w powstanie artykułu / percentage contribution - 70\%;
} 
Method: The paper presents research results for electrostatic properties of products. From an examination of electric parameters; static (surface, cross-sectional and point to point resistance) and dynamic (discharge lead time, capability to electrify, electrical field strength), and based on the stability of electrical parameters over a time period as well as impact on the environment involved with the manufacture of anti-static products, the authors identified a production process for anti-static products, which is revealed in the publication. Selected products represented a range of different approaches and methods of realising the process. Although technology for manufacturing antistatic products is known, nevertheless, it is not thoroughly recognised or described, among other things, in context of durability over time. An anti-static condition is a process of increasing the dissipation (discharge) of static electricity over time. The decisive influence on the speed of dissipation is the electrical capacitance and electrical resistance of the product. Attainment of an anti-static condition is dependent on the modification of two product parameters. Namely, a change to electrical capacitance and change to electrical resistance of products. Results: As part of research work, performed at the Central Mining Institute since 2012, a series of extensive studies were conducted, which, in view of their diverse nature and type, culminated in a proposed partition of anti-static approaches. Based on several studies of a vast range of products and materials, the proposed partition of techniques to achieve anti-static conditions extends and complements existing methods revealed in specialist literature.

Conclusions: Results from this work can be used in the design of plastic manufacturing processes, with a focus on developing technology for the production of anti-static products, which remain stable over time and to analyze the risk associated with the use of such products.

Keywords: static electricity, electrostatics, anti-static process, charging test, resistance

Type of article: original scientific article

\section{АННОТАЦИЯ}

Цель: Пластики, принадлежащие по классификации к электрическим изоляторам, не соответствуют критериям польских и международных стандартов [1], [2], [3], [4] и польского законодательства [5] относительно антистатических свойств, поэтому не могут быть допущены к использованию в зонах, находящихся под угрозой взрыва. Для соблюдения требований вышеуказанных стандартов и положений, а также для получения антистатического изделия и снижения риска появления электростатического разряда, который может стать источником взрыва, пластики подвергаются процессу антистатизации - то есть улучшения антистатических свойств (в основном, уменьшении электрического сопротивления и удельного сопротивления).

Проект и методы: Представлены результаты проведенных исследований электростатических свойств изделий. Из анализа электрических, статических (поверхностное электрическое сопротивление, объемное сопротивление и сопротивление между точками) и динамических (время исчезновения электрического заряда, способность к электризации, напряженность электрического поля) параметров и на основе анализа стабильности во времени электрических параметров, влияния на среду антистатизированных изделий, получена авторская характеристика процесса антистатизации, которая представлена в публикации. Выбраны изделия, представляющие различные методы и способы реализации этого процесса. Хотя технология антистатизации общеизвестна, она ещё не вполне изучена и описана, что касается её устойчивости во времени. Антистатизация является процессом, заключающимся в повышении скорости рассеивания электрических разрядов. На скорость рассеивания основное влияние имеет электрическая ёмкость изделия и его электрическое сопротивление. Антистатизация заключается в модификации двух параметров изделий: изменении электрической ёмкости и изменении электрического сопротивления изделий.

Результаты: В рамках исследовательской работы, реализуемой в Главном Институте Горного Дела с 2012 года, проведен ряд комплексных исследований, которые позволили предложить классификацию техник антистатизации относительно ее разнооразного характера и типа. На основе ряда исследований большого количества различных изделий и материалов предложено разделение техник антистатизации, которое является расширением и дополнением имеющихся в специальной литературе классификаций.

Выводы: Результаты работы могут быть использованы при проектировке процессов обработки пластиков с целью разработки технологии производства антистатических изделий, свойства которых устойчивы во времени и с целью анализа риска, связанного с электризацией изделия.

Ключевые слова: статическое электричество, электростатика, антистатизация, электризация, электрическое сопротивление Вид статьи: оригинальная научная статья

\section{Wstęp}

Zapłon opar paliwa podczas tankowania samochodu na stacji paliw [7] jest przykładem zagrożenia związanego ze zjawiskiem elektryczności statycznej. Jego przyczyną jest nadmierna elektryzacja skutkująca wyładowaniem elektrostatycznym, które powoduje zapłon albo wybuch mieszanin wybuchowych.

Elektryczność statyczna jest zjawiskiem powszechnym, a związana jest z powstaniem ładunków nadmiarowych. Nadmiarowe ładunki elektrostatyczne powstają podczas tarcia, rozdzielania lub indukcji. Wyładowania elektrostatyczne niosą za sobą negatywne skutki zarówno dla człowieka, jak i urządzeń (szczególnie urządzeń elektronicznych) oraz wyrobów. Wyładowania elektrostatyczne niosą zagrożenie wybuchem i pożarem w strefach potencjalnie wybuchowych.

Tworzywa sztuczne $z$ reguły nie są antystatyczne, to znaczy elektryzują się, gromadząc nadmiarowy ładunek elektryczny, co stanowi zagrożenie wystąpienia wyładowania elektrostatycznego, które może zainicjować wybuch atmosfery wybuchowej, może zniszczyć urządzenie elektroniczne lub może wpłynąć negatywnie na człowieka poprzez przepływ przez ciało prądu wyładowania stanowiącego zagrożenie dla zdrowia. 
Oczywiste jest, że tworzywa sztuczne stosowane jako materiały izolacyjne nie spełniają kryteriów polskich i międzynarodowych norm [1], [2], [3], [4] i polskiej legislacji [5] odnośnie właściwości antyelektrostatycznych, wobec czego nie mogą być dopuszczone do użytkowania w strefach zagrożonych wybuchem. W celu spełnienia wymagań wyżej wymienionych norm i przepisów, uzyskania wyrobu antystatycznego oraz obniżenia ryzyka wyładowania elektrostatycznego mogącego być inicjatorem wybuchu tworzywa sztuczne poddaje się antystatyzacji, czyli poprawianiu właściwości antyelektrostatycznych [9] (głównie zmniejszeniu rezystancji i rezystywności).

Ubranie pracownika wspomnianej stacji paliw wykonującego swoje obowiązki w momencie, gdy doszło do zdarzenia, czyli wybuchu opar paliwa, najprawdopodobniej nie było antyelektrostatyczne lub straciło po pewnym czasie właściwości antyelektrostatyczne.

W publikacji podjęto się opisu i usystematyzowania technologii antystatyzacji. Autorzy publikacji proponują podział techniki antystatyzacji z uwagi na cechy procesu antystatyzacji, ale również ze względu na trwałość procesu antystatyzacji.

Oddziaływania elektryczności statycznej należy podzielić na trzy grupy [8]:

- negatywne skutki wyładowania odczuwane przez człowieka,

- negatywne skutki wyładowania wpływające na ESDS (Electro Static Sensitive Device - Obiekt wrażliwy na wyładowania elektrostatyczne),

- zapłon albo wybuch mieszanin wybuchowych w strefach zagrożonych wybuchem.

W elektrostatyce wprowadzono podział materiałów [1], [2]. [3], [4], [6], [9], [12] na trzy grupy: materiały przewodzące, materiały rozpraszające i izolatory. Kryterium podziału najczęściej jest rezystancja powierzchniowa $\left(\mathrm{R}_{\mathrm{S}}\right)$ lub rezystancja skrośna $\left(\mathrm{R}_{\mathrm{v}}\right)$. Wyróżnia się materiały: przewodzące, które wykazują rezystancję $<10^{5} \Omega$, materiały rozpraszające $>10^{5} \Omega \mathrm{i}<10^{9} \Omega$, izolatory $>10^{9} \Omega /$.

Wiele materiałów zmienia swoje właściwości elektrostatyczne w czasie. Jest to związane $\mathrm{z}$ tym, że materiały te wykonane są $z$ antystatyzowanych i uniepalnianych tworzyw sztucznych. Technologie antystatyzacji są znane i powszechnie stosowane [10], [11] przez producentów tworzyw sztucznych, którzy swoje produkty dostarczają do stref potencjalnie wybuchowych, gdzie parametry elektrostatyczne wyrobów są regulowane przez polskie i europejskie prawo. Pomimo że technologie antystatyzacji są znane, to nie są one dogłębnie rozpoznane, zbadane i scharakteryzowane. Istnieje kilka pozycji literaturowych na temat antystatyzacji, lecz są to opracowania, których nie da się wykorzystać w szerszym zakresie ze względu na ich szczegółowy charakter.

Wielu producentów antystatyzuje swoje wyroby wykonane $\mathrm{z}$ tworzyw sztucznych, nie zdając sobie sprawy $\mathrm{z}$ tego, że te własności ulegają zanikowi, a parametry rezystancyjne wyrobów zmieniają się w czasie. Świadomość nietrwałości wybranych metod antystatyzacji przejawiać się może w postępowaniu odbiorcy, który do użytkowania dopuszcza odzież, której właściwości antystatyczne muszą spełniać założone kryteria zarówno po wyprodukowaniu wyrobu, jak i po pięćdziesięciu praniach wyrobu.

\section{Antystatyzacja}

Antystatyzacja jest procesem polegającym na zwiększeniu szybkości rozpraszania (odprowadzania) ładunków. Antystatyzacja ma na celu zmianę parametrów rezystancyjnych materiałów, często zmianę kategorii tworzywa sztucznego z izolatora na materiał rozpraszający.

Kinetyka rozładowania z naelektryzowanego materiału do uziemienia [12] jest opisana funkcją wykładniczą (1)

$Q=Q_{0} \times e^{-\frac{t}{\tau}}$

gdzie:

- maksymalna wartość ładunku po naelektryzowaniu

- stała czasowa rozładowania równa

Po przekształceniu stałej czasowej, wzór (1) otrzymuje postać (2)

$Q=Q_{0} \times e^{-\frac{t}{R C}}$

Ze wzoru (2) wynika, że na szybkość rozładowania decydujący wpływ ma pojemność elektryczna i rezystancja wyrobu. Antystatyzacja polega na modyfikacji dwóch parametrów wyrobów: zmianie pojemności elektrycznej C oraz zmianie rezystancji elektrycznej wyrobów R.

\subsection{Zwiększanie pojemności elektrycznej układu}

Zwiększenie pojemności elektrycznej układu ma na celu osłabienie wyładowań elektrostatycznych. Warunkiem powstania wyładowania jest istnienie odpowiednio dużej różnicy potencjałów. Przekształcając wzór (3) określający ładunek elektrostatyczny:

$Q=C x U$

można otrzymać postać(4) dla potencjału elektrostatycznego:

$U=\frac{Q}{C}$

Z formuły (4) wynika, że potencjał jest wprost proporcjonalny do wartości ładunku i odwrotnie proporcjonalny do pojemności układu. Zwiększając pojemność układu zmniejsza się potencjał układu.

\subsection{Zwiększenie przewodności elektrycznej materiałów}

Zwiększanie przewodności elektrycznej materiałów jest kolejną z metod antystatyzacji [4]. Skutkiem antystatyzacji wyrobów jest zmniejszenie rezystancji powierzchniowej $\left(\mathrm{R}_{\mathrm{S}}\right)$ lub rezystancji skrośnej $\left(\mathrm{R}_{\mathrm{v}}\right)$ wyrobu, co skutkuje zmianą klasyfikacji wyrobu (np. z izolatora na rozpraszający).

\subsection{Podział procesu antystatyzacji ze względu na typy}

W ramach pracy badawczej [13], realizowanej w Głównym Instytucie Górnictwa w 2012 roku, przeprowadzono szereg kompleksowych badań, które zaowocowały zaproponowaniem podziału technik antystatyzacji ze względu na typy. Wprowadzono rozszerzone w stosunku do prezentowanych w literaturze [10] i [14], kryteria podziału technologii antystatyzacji. 


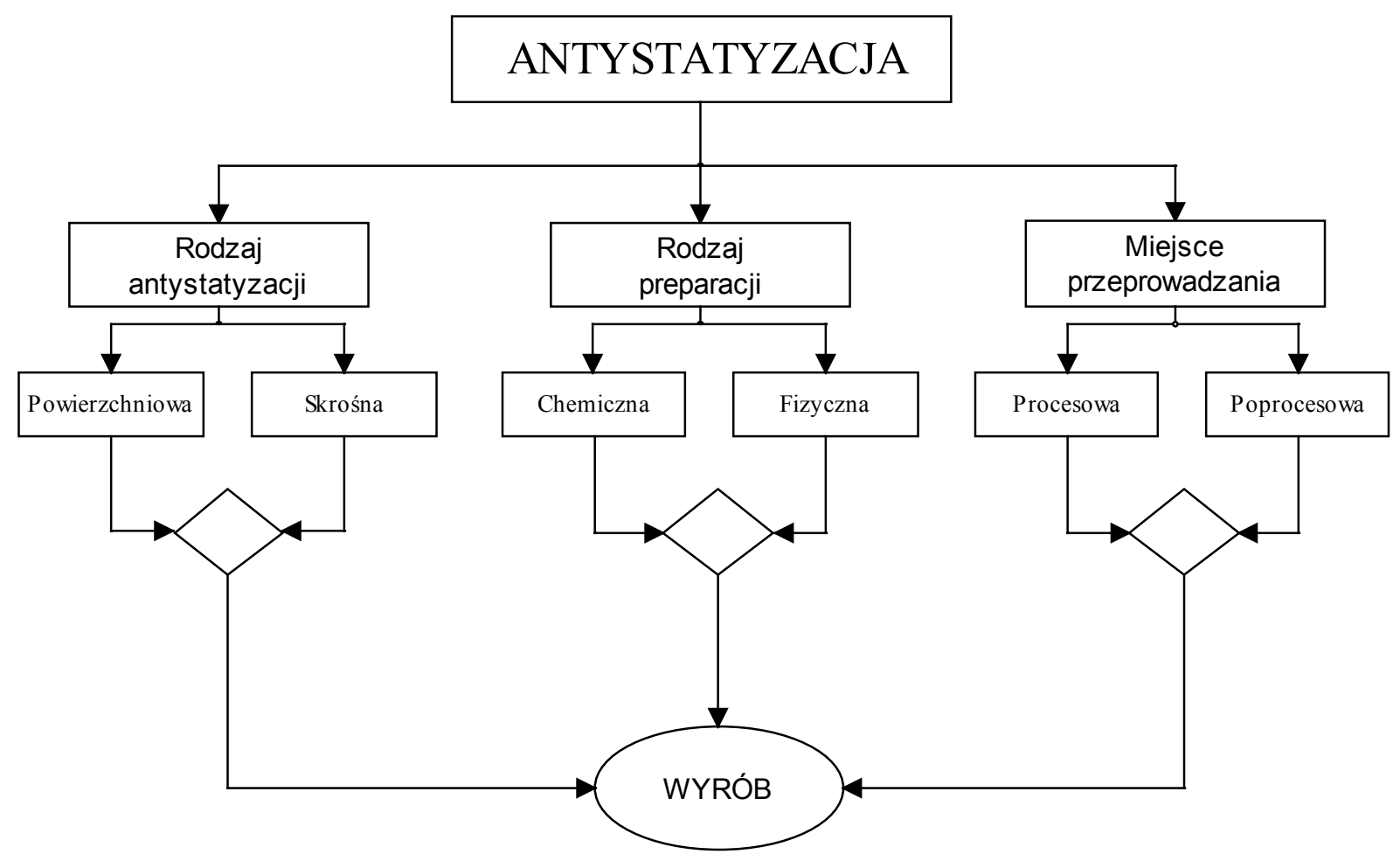

Ryc. 1. Podział techniki antystatyzacji Źródło: Opracowanie własne.

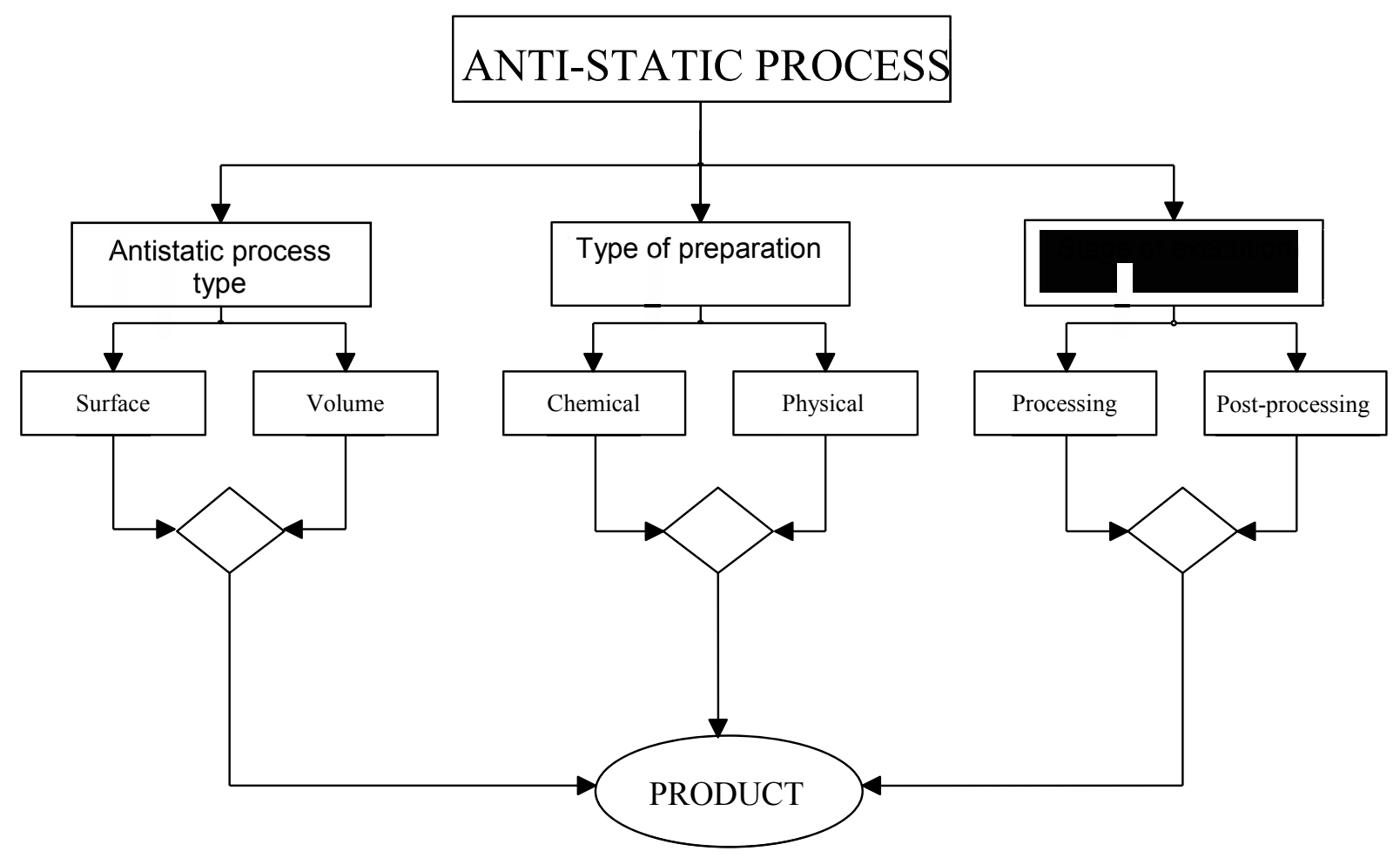

Fig. 1. Partition of the anti-static process Source: Own elaboration. 
Każdy wyrób antystatyzowany można rozpatrywać według trzech typów antystatyzacji - ze względu na rodzaj antystatyzacji, rodzaj preparacji i miejsce przeprowadzenia) lub łącznie, jako jeden z ośmiu rodzajów materiałów antystatyzowanych:

- powierzchniowo chemicznie procesowo,

- powierzchniowo chemicznie poprocesowo,

- powierzchniowo fizycznie procesowo,

- powierzchniowo fizycznie poprocesowo,

- skrośnie chemicznie procesowo,

- skrośnie chemicznie poprocesowo,

- skrośnie fizycznie procesowo,

- skrośnie fizycznie poprocesowo.

Antystatyzacja powierzchniowa - proces antystatyzacji ma na celu zmniejszenie rezystancji powierzchniowej wyrobu. Antystatyzacja powierzchniowa realizowana jest przez pokrycie powierzchni tlenkami metali, wprowadzenie powłok metalowych lub powłok węglowych [14] na przykład antystatyzacją powierzchniową jest ekranowanie.

Antystatyzacja skrośna - proces antystatyzacji mający na celu zmniejszenie rezystancji skrośnej wyrobu. Zwiększenie przewodności skrośnej można osiągnąć za pomocą dodatków takich antystatyków jak sadza, grafit, opiłki i włókna metalowe [12].

Antystatyzacja chemiczna - poprzez wprowadzenie dodatku w procesie antystatyzacji. Jest realizowana poprzez dodanie odpowiedniego środka chemicznego. Obróbka chemiczna (chemiczna preparacja) jest bardzo rozpowszechnioną metodą w przemyśle włókienniczym i produkcji tworzyw sztucznych. Efektem ingerencji chemicznej jest utworzenie warstwy o określonej przewodności elektrycznej. Wiele z tych preparatów chłonie wilgoć przy określonym poziomie wilgotności względnej powietrza. Tkanina staje się antystatyczna przy pewnej wilgotności względnej powietrza. Często używanymi dodatkami antystatycznymi są elektrolity.

Antystatyzacja fizyczna - polega na wprowadzeniu do materiału antystatyzowanego dodatków przewodzących (domieszek). Antystatyzację fizyczną stosuje się przy produkcji dzianin, których przykładowo $98 \%$ składu stanowi poliester, a $2 \%$ włókno węglowe. Rozpowszechnione w produkcji wyrobów wykonanych w technice przeplotu jest wplatanie cienkich drutów metalowych. Antystatyzacja fizyczna cechuje się większą trwałością niż antystatyzacja chemiczna, ze względu na większą trwałość antystatyku (nitki węglowe) i braku zależności od wilgotności względnej powietrza (higroskopijność chemicznych antystatyków).

Antystatyzacja poprocesowa - antystatyzacja tego typu jest przeprowadzana po wyprodukowaniu wyrobu. Proces antystatyzacji nie jest związany z procesem produkcji i często wykonywany jest $\mathrm{w}$ innym miejscu niż zakład produkcyjny.

Antystatyzacja procesowa - ten typ antystatyzacji wymaga modyfikacji linii technologicznej i produkcyjnej. Przykładem antystatyzacji procesowej jest wprowadzanie domieszki włókien przewodzących do tkaniny.

\subsection{Trwałość antystatyzacji}

Badania trwałości [13] przeprowadzonych procesów antystatyzacji wyrobów przeprowadzono w Głównym Instytucie Górnictwa w 2012 roku. Poniżej przedstawiono wybrane wyniki badań właściwości elektrostatycznych wyrobów przeprowadzonych cyklicznie w dłuższym okresie czasu. Każdy wyrób został zakwalifikowany według podziału zaproponowanego na ryc. 1 .

Wykładziny podłogowe - wyrób według kryteriów (ryc. 1) podlega podziałom na:

- antystatyzowany skrośnie (o czym świadczy niska rezystancja powierzchni względem uziemienia),

- preparowany fizycznie (poprzez wprowadzenie dodatku),

- antystatyzowany procesowo (antystatyzację przeprowadzono na etapie produkcji wyrobu).

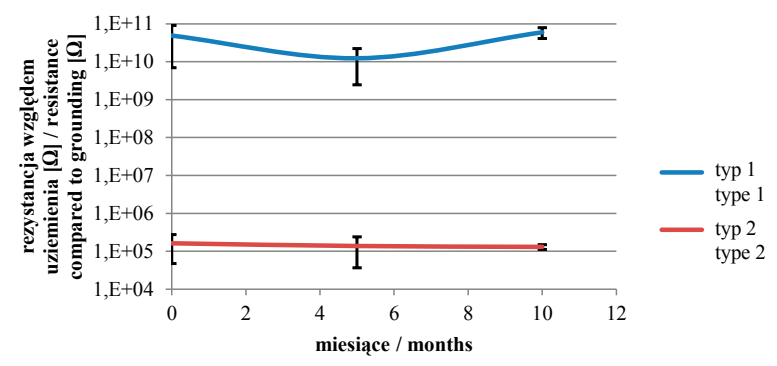

Ryc. 2. Rezystancja między punktami dwóch typów wykładzin podłogowych

Fig. 2. Point-to-point resistance of two types of flooring

Źródło: Opracowanie własne.

Source: Own elaboration.

W okresie 10 miesięcy zachowuje swoje właściwości na niezmiennym poziomie, co świadczy o stabilności procesu antystatyzacji.

Fartuch antyelektrostatyczny - wyrób według kryteriów (ryc. 1) podlega podziałom na:

- antystatyzowany skrośnie (o czym świadczy niska rezystancja powierzchni względem uziemienia),

- preparowany fizycznie (poprzez wprowadzenie dodatku w formie włókien przewodzących),

- antystatyzowany procesowo (antystatyzacje przeprowadzono na etapie produkcji wyrobu).

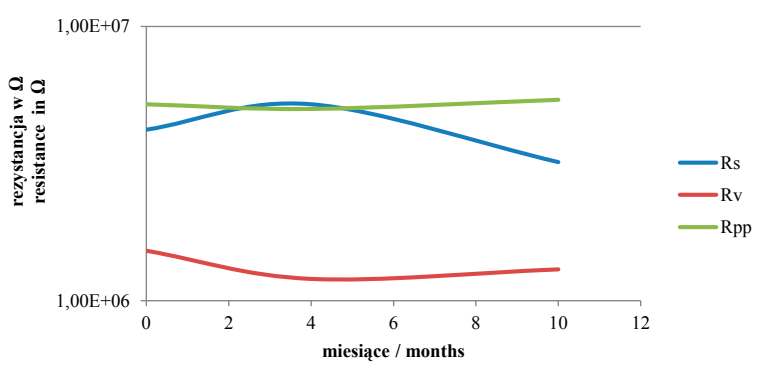

Ryc. 3. Rezystancja fartucha antystatycznego

Fig. 3. Resistance of an anti-static apron

Źródło: Opracowanie własne. Source: Own elaboration. 
Tkanina z przeplotem metalowym - wyrób według kryteriów (ryc. 1) podlega podziałom na:

- antystatyzowany skrośnie (o czym świadczy niska rezystancja powierzchni względem uziemienia),

- preparowany fizycznie (poprzez wprowadzenie dodatku włókien przewodzących),

- antystatyzowany procesowo (antystatyzację przeprowadzono na etapie produkcji wyrobu).

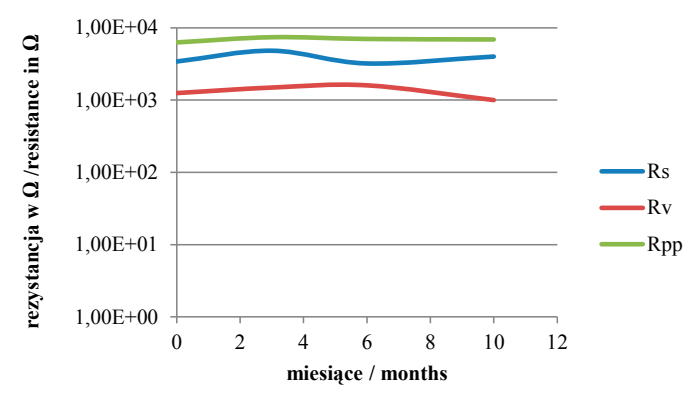

Ryc. 4. Rezystancja tkaniny z przeplotem metalowym

Fig. 4. Resistance of a metal-interlaced fabric

Źródło: Opracowanie własne. Source: Own elaboration.

Tkanina antystatyzowana - wyrób według kryteriów (punkt 2.3. ryc. 1) podlega podziałom na:

- antystatyzowany powierzchniowo (wyrób pokrywany poprzez spryskanie),

- preparowany chemicznie,

- antystatyzowany poprocesowo.

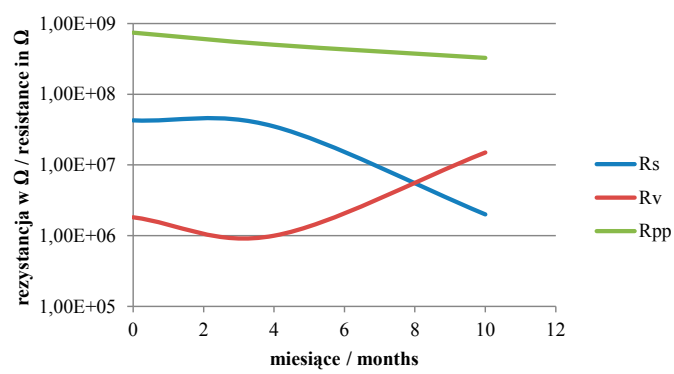

Ryc. 5. Rezystancja tkaniny typ 1 (opracowanie własne)

Fig. 5. Resistance of type 1 fabric

Źródło: Opracowanie własne.

Source: Own elaboration.

Tkanina antystatyzowana - wyrób według kryteriów (ryc. 1) podlega podziałom na:

- antystatyzowany skrośnie (o czym świadczy dodanie antystatyku na etapie produkcji nitek, z których wykonuje się tkaninę),

- preparowany chemicznie (przez dodatek włókien przewodzących),

- antystatyzacja procesowa (antystatyzację przeprowadzono na etapie produkcji wyrobu).

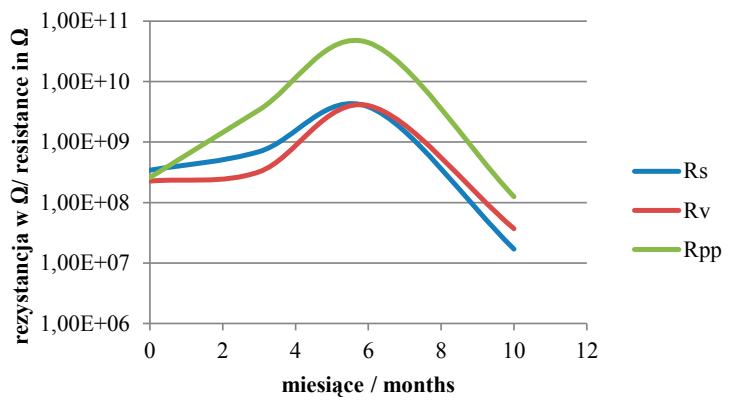

Ryc. 6. Rezystancja tkaniny typ 2

Fig. 6. Resistance of type 2 fabric Źródło: Opracowanie własne. Source: Own elaboration.

\section{Podsumowanie}

Technologia antystatyzacji, pomimo szerokiego stosowania w przemyśle przetwórstwa tworzyw sztucznych, nie doczekała się jeszcze kompleksowego opracowania literaturowego. Najbardziej aktualne informacje literaturowe pochodzą z końca lat 80 . XX wieku oraz $\mathrm{z}$ wąsko tematycznych publikacji w specjalistycznych czasopismach bez szans na zastosowanie ogólne. W publikacji podano rozszerzoną względem dotychczas znanych [9], [11] i [12].

Antystatyzację stosuje się w celu obniżenia możliwości naelektryzowania się wyrobu w czasie jego eksploatacji. Utrzymanie początkowych właściwości materiałów w czasie jest bardzo istotne w odniesieniu do ich stosowania w atmosferze potencjalnie wybuchowej, szczególnie występującej w kopalniach węgla kamiennego.

W czasach szerokiego wykorzystania w przemyśle tworzyw sztucznych coraz częściej dochodzi do zagrożeń związanych z elektryzacją wyrobów i brakiem zdolności do odprowadzenia nadmiarowego ładunku poprzez wyrób. Tworzywa sztuczne w celu eliminacji lub zmniejszenia ryzyka powstania ładunku elektrycznego są antystatyzowane - czyli polepszane - z punktu widzenia parametrów elektrostatycznych.

$\mathrm{W}$ artykule przedstawiono autorską propozycję podziału technologii antystatyzacji [13]. Istotnym wnioskiem wynikającym z prac naukowych [13], [16] podejmowanych w Głównym Instytucie Górnictwa, jest zależność trwałości parametrów w czasie i sposób oddziaływania na środowisko od procesu antystatyzacji.

Poniższe wnioski zostały wyciągnięte $\mathrm{z}$ badań i prac, których konkluzje opisano w publikacji:

- parametry elektrostatyczne wyrobów antystatyzowanych fizycznie są trwalsze w czasie niż wyrobów antystatyzowanych chemicznie. Antystatyzacja (preparacja) fizyczna (dodanie do wyrobu dodatku będącego ciałem stałym) nie zanika w czasie, tak jak to się dzieje $\mathrm{z}$ preparacją chemiczną (dodanie do wyrobu dodatku będącego środkiem chemicznym), ponieważ ciało stałe nie wypłukuje się, nie ulega reakcjom chemicznym, ani nie kruszy się [10], 
- wyrób antystatyzowany chemicznie poprocesowo charakteryzuje się dużą niepewnością wyników parametrów elektrostatycznych,

- wyrób antystatyzowany fizycznie charakteryzuje się małą niepewnością wyników parametrów elektrostatycznych, jednak jest to uzależnione od umieszczenia antystatyku - ciała stałego (nitek węglowych, metalowych lub innych ciał fizycznych stałych) i doboru metody badania rezystancji powierzchniowej (średnicy elektrody, odległości między elektrodami itp.),

- wyrób antystatyzowany procesowo jest trwalszy w czasie niż wyrób antystatyzowany poprocesowo, ponieważ w przypadku antystatyzacji procesowej polepsza się półprodukt albo surowiec dla gotowego wyrobu. W przypadku antystatyzacji poprocesowej polepszeniu poddaje się gotowy, wyprodukowany wyrób.

Antystatyzacja tworzyw sztucznych zwraca uwagę służb bezpieczeństwa i nadzoru na bezpieczeństwo wybuchowe i pożarowe w strefach potencjalnie wybuchowych oraz wszędzie tam, gdzie występują mieszaniny wybuchowe gazów lub par z powietrzem, pyły wybuchowe, ciecze palne oraz mgły palne.

\section{Literatura}

[1] Raport techniczny CLC/TR 50404 z czerwca 2003 Elektrostatyka - Kodeks postępowania praktycznego dla unikania zagrożeń związanych z elektrycznością statyczną.

[2] Technical Specification IEC/TS 60079-32-1:2013 Explosives atmospheres - Part 32-1: Electrostatic hazards, guidance.

[3] PN-EN 13463-1:2010 Urządzenia nieelektryczne w przestrzeniach zagrożonych wybuchem. Część 1: Podstawowe założenia i wymagania.

[4] PN-E-05203 Ochrona przed elektrycznościa statyczną. Materiaty $i$ wyroby stosowane $w$ obiektach oraz strefach zagrożonych wybuchem. Metody badania oporu elektrycznego właściwego i oporu upływu.

[5] Wyższy Urząd Górniczy Departament Prawny, tekst jednolity Rozporządzenie Ministra Gospodarki z dnia 28.06.2002 w sprawie bezpieczeństwa i higieny pracy, prowadzenia ruchu oraz specjalistycznego zabezpieczenia przeciwpożarowego $\mathrm{w}$ podziemnych zakładach górniczych.

[6] Raport techniczny CLC/TR 50404 z czerwca 2003 Elektrostatyka - Kodeks postępowania praktycznego dla unikania zagrożeń związanych z elektrycznością statyczną.

[7] https://www.youtube.com/watch?v=tuZxFL9cGkI film pt. "Gas Station Fire, Static Electricity Starts a Flash Fire".

[8] www.elektrostastyka.gig.eu

[9] Strojny J., Elektryczność statyczna w pytaniach i odpowiedziach, WNT, 1979.

[10] Rydarowski H., Tworzywa sztuczne w górnictwie - nowe tendencje, „Wiadomości Górnicze”, Issues 7-8, 2005.

[11] Bieniek D., Antidotum na elektryczność statyczna w tworzywach, „Rynek Tworzyw”, Issue 9, 2006.

[12] Gajewski A., Elektryczność statyczna: poznanie, pomiar, zapobieganie, eliminacja, Instytut Wydawniczy Związków Zawodowych, 1987.

[13] Kędzierski P., Dokumentacja pracy statutowej Badanie właściwości materiałów antystatycznych $w$ zależności od czasu użytkowania, Główny Instytut Górnictwa, 2012.

[14] Simorda J., Staroba J., Elektryczność statyczna w przemyśle, WNT, 1970.

[15] Pazdro K., Uwaga elektryczność statyczna, Instytut Wydawniczy CRZZ, 1972.

[16] Kędzierski P., Wpływ czasu użytkowania wyrobów na wartości parametrów rezystancyjnych, $\mathrm{X}$ Jubileuszowe Sympozjum El-Tex Pola Elektrostatyczne i Elektromagnetyczne - nowe materiały i technologie, 2012.

\section{Użyte skróty:}

Q - ładunek elektrostatyczny w kulombach,

$\mathrm{Q}_{0}$ - początkowy ładunek elektrostatyczny w kulombach,

$\mathrm{t}$ - czas w sekundach,

$\mathrm{T}$ - stała czasowa,

$\mathrm{R}$ - rezystancja w omach,

$\mathrm{R}_{\mathrm{S}}$ - rezystancja powierzchniowa w omach,

$\mathrm{R}_{\mathrm{V}}$ - rezystancja skrośna w omach,

$\mathrm{R}_{\mathrm{PP}}$ - rezystancja między punktami w omach,

$\mathrm{C}$ - pojemność elektryczna $\mathrm{w}$ faradach,

$\mathrm{U}$ - napięcie elektrostatyczne $\mathrm{w}$ woltach,

ESDS - ElectroStatic Discharge Sensitive - produkt wrażliwy na wyładowania elektrostatyczne.

dr hab. Henryk Passia, prof. GIG - pracownik naukowy Głównego Instytutu Górnictwa w Katowicach i Wyższej Szkoły Zarządzania Ochroną Pracy w Katowicach. Zajmuje się problematyką zagrożeń fizycznych w środowisku pracy.

mgr inż. Przemysław Kędzierski - pracownik naukowy Głównego Instytut Górnictwa. Zajmuje się problematyką elektryczności statycznej (ESD) oraz działalnością prewencyjną w strefach zagrożonych wybuchem oraz w przemyśle elektronicznym. Certyfikowany Koordynator ESD. 